\title{
Performance Assessment of Dilute-Acid Leaching to Improve Corn Stover Quality for Thermochemical Conversion
}

\author{
John E. Aston ${ }^{1 \dagger}$, David N. Thompson ${ }^{1}$ and Tyler L. Westover ${ }^{2}$ \\ ${ }^{1}$ Biological and Chemical Processing Department, Idaho National Laboratory, U.S.A. \\ ${ }^{2}$ Idaho National Laboratory, Biofuels and Renewable Energy Technology Department, Idaho \\ National Laboratory, U.S.A. \\ †John.Aston@inl.gov \\ Idaho National Laboratory \\ P.O. Box 1625
}

Idaho Falls, Idaho 83415

Phone: 208-526-1851

Facsimile: 208-526-0828 


\begin{abstract}
Lignocellulosic biomass is a sustainable energy source that can help meet the increasing demand for biofuels in the United States. However, the quality and availability of such feedstocks greatly affect their suitability for downstream conversion. This work reports the effects of dilute-acid leaching at various aqueous loadings, temperatures and catalyst loadings (sulfuric acid) on the quality of a traditional biochemical feedstock, corn stover, as a potential feedstock for thermochemical conversions.
\end{abstract}

At $95 \mathrm{wt} \%$ aqueous, dilute-acid leaching was observed to effectively remove $97.3 \%$ of the alkali metals and alkaline earth metals that can negatively affect degradation pathways during pyrolysis and result in greater yield of non-condensable gases. In addition, up to $98.4 \%$ of the chlorine and $88.8 \%$ of the phosphorus, which can cause equipment corrosion and foul upgrading catalysts, respectively, were removed. At $25^{\circ} \mathrm{C}$ in the absence of the acid catalyst, only $6.8 \%$ of the alkali metals and alkaline earth metals were removed; however, $88.0 \%$ of chloride was still removed.

The ratio of alkaline/acidic ash species has been suggested to proportionately relate to slagging in combustion applications. The initial alkali/acid ratio of the ash species present in the untreated corn stover was 0.38 (significant slagging risk). At $95 \mathrm{wt} \%$ aqueous, this ratio was decreased to 0.18 (moderate slagging risk) at $0 \mathrm{wt} \%$ catalyst and $90^{\circ} \mathrm{C}$, and was decreased to $0.07,0.08$ and 0.06 at $0.5 \mathrm{wt} \%$ catalyst at $25^{\circ} \mathrm{C}, 50^{\circ} \mathrm{C}$ and $90^{\circ} \mathrm{C}$, respectively (low slagging risk). Increasing the catalyst loading to $1.0 \%$ slightly decreased the measured alkali/acid ratio of remaining ash.

The results presented here show that a water wash or a dilute-acid preprocessing step can improve corn stover quality for pyrolysis, hydrothermal liquefaction and combustion.

Key Words: Corn stover, pyrolysis, hydrothermal liquefaction, combustion, leaching, ash 


\section{Introduction}

More than one billion dry tons of lignocellulosic feedstocks are expected to be sustainably available in the United States by 2030, an amount that would potentially provide enough chemical energy to replace up to $30 \%$ of the United States' current petroleum consumption [1]. However, bioenergy is not yet a mature industry, and as such, an understanding of feedstock quality and its impacts on conversion are not widely understood [2, 3].

Three major conversion pathways for lignocellulosic feedstocks are biochemical (alcohol or organic acid fermentation), thermochemical (bio-oil formation through pyrolysis or hydrothermal liquefaction (HTL) or syn gas production through gasification) and combustion. Currently, feedstock quality specifications for these pathways are largely limited to total ash, organic content and sugar content. These attributes may be used to predict a potential yield, but do not account for inhibitors that affect reactivity, product degradation and/or corrode and foul conversion equipment.

Factors such as these have driven the selection of feedstocks for given conversion pathways. For example, the yield from biochemical conversion of lignocellulosic feedstocks to ethanol is more a function of cellulose and hemicellulose content and less so of ash content; because of this, high-ash herbaceous feedstocks such as corn stover are commonly used [4-6]. Conversely, woody biomass is often used for thermochemical conversions such as pyrolysis and HTL because the low ash content results in high yields with less catalytic poisoning, slagging and equipment fouling [7-10]. These considerations notwithstanding, to strengthen and secure the availability of feedstocks for the biofuels industry in the United States and globally, biorefineries must eventually consider adapting for more flexible feedstock availability and quality. 
One of the most prominent and widely available lignocellulosic feedstocks is corn stover. However, the relatively high amount of inorganic contaminants found in corn stover, and other agricultural residues, adds expense to the logistics, processing and conversion [11]. Further, many of the ash species that adversely affect thermochemical conversions are physiological, and therefore would require a chemical preprocessing step to be removed.

Existing chemical preprocessing methods that target the removal of physiological ash components are low-severity water and dilute-acid leaching. Water washing at temperatures from ambient to near boiling can remove exogenous ash components such as sodium, alumina, iron and silica introduced via soil entrainment [7]. However, significant removal of physiological ash components, including the bulk of the alkaline earth and alkali metals that are inhibitory to pyrolysis conversions, via their catalysis of secondary cracking of vapors and reduce bio-oil yield and quality, may require dilute-acid leaching [12-16]. Other chemical treatments may also be applied such as simple hot water washing, which may affect deacetylation and lower the $\mathrm{pH}$ of the wash media.

The research presented here tested the efficacy of water washing and dilute-acid leaching as a potential preprocessing method to improve the feedstock quality attributes of multi-pass corn stover for thermochemical conversion. Equilibrium water washing and two concentrations of an acid catalyst (sulfuric acid) were tested at three different aqueous loadings and temperatures. The effects on soluble convertible material, ash, ash composition and nitrogen content are reported here and discussed with respect to their relevance to pyrolysis, HTL and combustion. 


\section{Materials and Methods}

\section{1- Sample Collection}

Approximately 400 kilograms of multi-pass corn stover harvested in Boone County, Iowa (2012) was procured and stored at approximately $8 \mathrm{wt} \%$ moisture in a dry and covered condition until use. The stover was ground to pass a 1-inch $(25.4 \mathrm{~mm})$ screen using a Vermeer BG480 Hammer Mill (Pella, Iowa). After being milled, the stover was mixed in an overflow bin and stored in four super sacks. An eight-way star splitter was used to individually split the four super sacks of ground stover. After the first splitting, the splits from the four super sacks were recombined and mixed. The splitting and mixing process was repeated two additional times. The mixed stover was then divided into smaller aliquots of approximately $6.1 \mathrm{~kg}$. These aliquots were then mixed and split to create samples with masses of approximately $0.35,0.87$ and $1.75 \mathrm{~kg}$ to provide 98 $\mathrm{wt} \%, 95 \mathrm{wt} \%$ and $90 \mathrm{wt} \%$ aqueous loading (i.e., $2 \mathrm{wt} \%, 5 \mathrm{wt} \%$ and $10 \mathrm{wt} \%$ solids) for the water and dilute-acid leaching experiments. The aqueous loading by wt $\%$ represents the wt $\%$ of the final leaching media that is comprised of water and the sulfuric acid catalyst.

\section{2 - Leaching Protocol}

An acid catalyst, sulfuric acid, was used to improve the removal of alkali metals and alkaline earth metals. Table 1 shows the test matrix used to determine the effects of catalyst concentration, temperature and aqueous loading on the removal of organics during leaching.

Experiments were completed with a single replicate at each set of conditions, and an additional 9 experiments were completed to estimate experimental error. These included minimal leaching conditions (i.e. $0 \mathrm{wt} \%$ catalyst, $25^{\circ} \mathrm{C}$ and $90 \mathrm{wt} \%$ aqueous), moderate leaching conditions (0.5 wt $\%$ catalyst, $50^{\circ} \mathrm{C}$ and $95 \mathrm{wt} \%$ aqueous loading) and severe leaching conditions (1.0 wt $\%$ 
catalyst, $90^{\circ} \mathrm{C}$ and $98 \mathrm{wt} \%$ aqueous), each in triplicate. These experimental sets were carried out for twenty-four hours to achieve equilibrium conditions, which were verified by allowing separate experiments to continue for up to 72 hours. Even at the most mild conditions tested, $25^{\circ} \mathrm{C}, 90 \%$ aqueous and $0 \mathrm{wt} \%$ catalyst, the longer experiments did not result in total ash, potassium, sodium, magnesium, calcium, silica, iron or alumina measurements that were statistically different than the shorter tests, as evaluated by the calculation of $95 \%$ confidence intervals (data not shown). Additionally, from the initial untreated sample pool, six randomly selected samples were characterized to measure base-line ash composition for comparison against leached material.

Leaching media were prepared by adding acid catalyst $\left(\mathrm{H}_{2} \mathrm{SO}_{4}\right.$, Sigma Aldrich) and deionized (DI) water to the required volumes, dependent upon the desired aqueous loading, in a 30-liter aluminum pot. The leaching solution was then heated on hot plates to temperature for each experiment. The temperature was measured using calibrated thermocouples. While the solution heated, a randomly-selected split sample of untreated corn stover was placed inside a concentric cylindrical aluminum wire cage inside another 30-liter aluminum pot. Mixing was achieved using a 3.5" magnetic stir bar rotating within the open center of the concentric cage. When the leaching medium had reached the desired temperature, the solution was added to the pot/cage assembly and placed on a hot plate to maintain temperature.

After 24-hours, the cage assembly was removed and placed into a stainless-steel pot containing $12 \mathrm{~L}$ of DI water, agitated, and washed for 45 minutes. This step was repeated once more. In each instance of corn stover being transferred from a leachate or wash solution, the solution was filtered subsequently through American Standard Test Sieves with 420 um and 75 um mesh, (Humboldt, Elgin, Illinois), and the collected corn stover particulates were returned to the bulk 
sample. Materials used in the handling of the sample were washed thoroughly between samples. The wash solution was then filtered using the same method and collected material was returned to the bulk solids.

\section{3 - Preparation of Leached Material for Analytic Applications}

The leached and washed corn stover was dried in an oven at $105^{\circ} \mathrm{C}$ for 48 to 72 hours to reduce the moisture to below $2 \mathrm{wt} \%$. The dried samples were ground to pass a $2-\mathrm{mm}$ screen using a Thomas Wiley Laboratory Knife Mill (Model 4, 1 horse power; Thomas Scientific, New Jersey). The ground material was then divided into smaller representative samples for nitrogen and ash composition analysis. A Retsch ZM200 Ultra Centrifugal Mill (Haan, Germany) equipped with either a $0.2-\mathrm{mm}$ screen or a $0.08-\mathrm{mm}$ screen, respectively, was used to grind the samples for these analyses.

\section{4 - Total Ash and Nitrogen Analysis}

Samples ground to pass a $0.2-\mathrm{mm}$ screen were analyzed for proximate (total ash) and ultimate (nitrogen content) by the Biomass Feedstock National User Facility Analytical Laboratory at Idaho National Laboratory using American Society for Testing Materials International methods D317-07a and D3176-09, respectively.

\section{5 - Elemental Ash Analysis}

Samples ground to pass a 0.08-mm screen were sent to Huffman Laboratories (Golden, Colorado) for ash composition analysis. A brief description of the methods used is given here. The samples were well mixed with lithium metaborate in a platinum crucible and fused for a fixed time at $950^{\circ} \mathrm{C}$. The cooled crucible was placed into a new polypropylene bottle containing $100.0 \mathrm{~mL}$ of dilute acid and shaken for several hours on a mechanical shaker until the fusion 
bead completely dissolved from the crucible. This resulting solution was analyzed by inductively coupled plasma - atomic emission spectroscopy for major and minor ash elements. Sample concentrations for individual elements were calculated based on ash weight and then converted to equivalent element oxides. This allowed for summation of the oxides and comparison to $100 \%$ as a means of analytical closure for quality control purposes.

\section{6 - Multivariate Analysis}

In order to simplify and generalize the trends observed in the data, multivariate least-squares analysis was performed on key response variables, including the percentages of organic material, total ash, potassium + sodium (alkali metals), and calcium +magnesium (alkaline earth metals) remaining after leaching as functions of the predictor variables aqueous loading, catalyst loading and temperature. Attempts were made using various equations to fit the data, including Arrhenius-type formulations; however, more sophisticated approaches did not yield significantly better fits than simple second-order polynomials. Step-wise regression was applied using a combination of calculations in Matlab ${ }^{\circledR}$ and Microsoft Excel ${ }^{\circledR}$ to determine equations that provided the most reasonable fits to the experimental data. These equations assumed linear contributions to ash and organics removal from temperature, catalyst loading and aqueous loading described by the experimental values of these terms multiplied by a constant. It also assumed linear contributions from interactions between each of these parameters described by the multiplication of these terms by each and a constant. Finally, the model considered secondary effects from these terms represented by squaring the experimental values and multiplying by a constant. The validity of each term was initially screen by $\mathrm{p}$-value calculations for each term. Pvalues greater than 0.05 resulted in the corresponding term being removed from the model, and the p-values for each remaining term being recalculated; this was repeated until all p-values were 
lower than 0.05 . Following a reduction in terms based on p-value calculations, fit quality was further judged by cross-validation and qualitatively by examining fit residuals to identify residuals with the least amount of observable systematic patterns. Cross-validation was performed by dividing the experimental results into four sub-sets. The first three sub-sets were used as calibration points, while the fourth sub-set was removed from the model and used for cross-validation. This process was repeated four times, removing a different sub-set of data each time, to produce four values of root mean square error of cross validation (RMSE-CV). The average of these four values was reported as the RMSE-CV of the model. Importantly, in the interest of simplicity as prescribed by relatively high uncertainty in the experimental data, second-order polynomial fits were selected as the most reasonable models. Consequently, the models are considered to be coarse engineering approximations, not precise chemical formulas.

\section{Results and Discussion}

\section{1 - Ash Composition of Untreated Multi-Pass Corn Stover}

Table 2 shows the total ash and ash composition of the untreated corn stover used in this study. These observations are consistent with published values [17-19], although due to the nature of harvest, multi-pass corn stover may vary significantly in both total ash and ash composition. These initial results were taken as a basis for each sample leached, and the percentage reductions of various ash constituents were calculated from these values and used to develop Figures 2-5. By mass, $7.7 \pm 1.0 \%$ of the corn stover was inorganic ash. This includes both introduced (e.g., iron, alumina, titania and soil-derived silica) and physiological ash (e.g., structural silica, phosphorus, alkaline earth metals, alkali metals and others). Because multi-pass corn stover was used in this study, significant amounts of ash were likely entrained during harvest. Ash is 
considered detrimental to conversion efficiency, equipment wear and waste handling; however, specific ash species affect conversion through different mechanisms. The relevance of the measured ash components are briefly discussed here.

Chlorine is a widely known corrosive when present in either pyrolysis vapor or deposited in slag on heat transfer surfaces [20]. In addition, chlorine may contribute to catalyst poisoning during catalyzed fast pyrolysis $[9,21]$. Like chlorine, nitrogen is not known to directly affect thermochemical reactions signifigantly; but does contribute to NOx gas formation [22] and, during HTL, reacts with degradation products to form solid deposits on catalyst surfaces [23-25]. Of particular interest to thermochemical conversion, ash in the corn stover contains relatively high amounts of alkali metals and alkaline earth metals, which affect pyrolysis kinetics, yield and change the reaction pathways and decomposition mechanisms as a function of temperature [26, 27]. Potassium, sodium, calcium and magnesium combined to represent $24.5 \pm 1.4 \mathrm{wt} \%$ of the ash in the multi-pass corn stover used in this study, or approximatley $1.9 \%(19,000 \mathrm{ppm})$ of the total feedstock. This is significantly higher than the 500 to 2,000 ppm of alkali metals and alkaline earth metals typically found in clean pine, which is a common feedstock for thermochemical conversions [28, 29]. Interestingly, unlike their inhibitory effects in pyrolysis, these ash species may serve as natural catalysts in HTL, resulting in larger molecular weight biooils, although the use of different catalysts may present the potential for these compounds to affect some undesirable catalyst poisoning [30]. Therefore, a chemical preprocessing step to improve feedstock quality for pyrolysis may make it less suitable for HTL.

Unlike the alkali metals and alkaline earth metals, silica is generally considered inert in pyrolysis and HTL reactions [31]. Although, recent work suggests that $\mathrm{SiO}_{2}$ may catalyze the cracking of polymeric molecules, resulting in increased char and non-condensable gas formation [32]. 
Similarly, in the presence of alkali metals and alkaline earth metals, phosphorus may foul upgrading catalysts [33], and increase char formation and destabilize pyrolysis oils by catalyzing condensation reactions [34]. In addition, the formation of phosphoric acid may necessitate neutralization and disposal [35]. Beyond a contribution to the overall ash content, iron and titania are not widely considered to be significantly inhibitory to common thermochemical conversion pathways.

In addition to inhibiting pyrolysis, potassium and silica may contribute to slag formation during combustion by forming $\mathrm{K}_{2} \mathrm{SiO}_{4}$, a eutectic with a low melting point. This low-melting point may lead to glass formation that will cause slagging, and may trap corrosives such as chloride on a reactor surface $[36,37]$.

\section{2 - Effect of Dilute-Acid Leaching on the Ash Composition of Multi-Pass Corn Stover}

Before considering the full set of leaching results, it is helpful to establish the uncertainty and repeatability of the measurements and establish general trends using replicate tests. For this purpose, three conditions corresponding to the least severe and most severe leaching conditions, as well as an intermediate condition were each repeated three times. The results of the replicate tests are shown in Figure 1 as a reduction of each species on a dry basis as a percent of total mass. For example, the total ash content of the samples before leaching is assumed to be $7.66 \%$ with a $95 \%$ confidence interval of $0.45 \%$. After leaching, the average ash content of the three samples leached at the least severe conditions was $5.90 \%$, representing a $1.8 \%$ decrease in total ash content, as shown in Figure 1. The uncertainty bars for the measurements of reduction of different species shown in Figure 1 were estimated following the development by Figliola and Beasley [38] and are given by 


$$
U_{R_{-} i}=\sqrt{\frac{1}{6} t_{5,95}^{2}\left(\left.s d_{i}\right|_{B . L .}\right)^{2}+\frac{1}{2} t_{2,95}^{2}\left(\left.s d_{i}\right|_{A . L .}\right)^{2}} \quad \text { Equation } 1
$$

where " $i$ " refers to the species $i$, and $s d_{i}$ is the standard deviation of measuring species $i$. The subscripts "B.L." and "A.L." refer to before and after leaching, respectively. Increased leaching severity removed greater amounts of potassium, calcium, magnesium and phosphorus. In contrast, sulfur and sodium became more concentrated in the corn stover leached at mid-severity and high-severity, conditions, respectively. It may be noted that sulfur is derived from both inorganic and organic sources in biomass feedstocks. The methods used here would not be considered ideal for targeting the organic sulfur sources, which would typically require alkaline or otherwise solvation methods of the cellular structure to liberate sulfur bound in thiol-protein groups. Therefore it is not surprising that sulfur was concentrated with respect to other ash species in the leached material. In addition, silicon also appeared to become more concentrated with increased leaching severity, although the increase was not statistically significant because of variation in silicon analyses. The overall result is that increasing severity of the leaching process had a greater effect on individual ash species than it did on the total concentration of ash.

Table 3 shows the full set of leaching results using water and dilute-acid at temperatures between 25 and $90^{\circ} \mathrm{C}$ at $98 \mathrm{wt} \%, 95 \mathrm{wt} \%$ and $90 \mathrm{wt} \%$ aqueous. These results are comparable to those observed in previous work using various feedstocks including switchgrass, corn stover and bark $[12-16,36]$, with respect to the effects of conditions on ash removal and the order-of-magnitude of removal for various ash species. However, studies under similar conditions using corn stover are lacking, as the majority of dilute-acid leaching work at relatively mild conditions has focused on woody feedstocks for ash removal. Conversely, dilute-acid leaching studies using herbaceous feedstocks often have focused on higher temperatures that affect the release of hemicellulose for 
biochemical conversion applications. In contrast, the purpose of this work was to study ash removal in a temperature regime that minimized the extraction of material convertible by thermochemical applications.

Generally speaking, the removal of total ash and ash species increased with increasing aqueous loading and increasing temperature. The exception was nitrogen, which was not removed to a significant extent, and the removal that was measured was not a function of catalyst concentration, aqueous loading or temperature. This indicates that that the conditions tested did not affect structural changes necessary to release significant amounts of protein, where large amounts of cellular proteins are located, from the biomass cells.

The parameter observed to have the smallest step-wise effect on ash removal was aqueous loading between $95 \mathrm{wt} \%$ and $90 \mathrm{wt} \%$, possibly suggesting some solubility limitations in the experimental set-up. Conversely, temperature had a significant effect on ash removal. Using the unleached stover as a basis (Table 2), in the absence of the catalyst, $10.4 \%$ ash reduction was observed using $98 \mathrm{wt} \%$ aqueous at $25^{\circ} \mathrm{C}$. However, increasing the temperature to $90^{\circ} \mathrm{C}$ resulted in a $41.6 \%$ increase in ash reduction.

When the catalyst was added, similar to the water-only leaching results, total ash and ash species removal trended with temperature and aqueous loading. However, the data in Tables 2 and 3 suggests that the addition of catalyst increased ash removal to a greater extent at lower temperatures than it did at higher temperatures. For example, at $98 \mathrm{wt} \%$ aqueous and $25^{\circ} \mathrm{C}$, ash reduction increased from $10.2 \%$ to $37.2 \%$ when catalyst was added to $0.5 \mathrm{wt} \%$; however, at 98 $\mathrm{wt} \%$ aqueous and $90^{\circ} \mathrm{C}$, ash reduction only increased from $41.6 \%$ to $43.9 \%$ when catalyst was added to $0.5 \mathrm{wt} \%$. 
At the most severe conditions tested, dilute-acid leaching $\left(1.0 \mathrm{wt} \%\right.$ catalyst, $90^{\circ} \mathrm{C}$ and $98 \mathrm{wt} \%$ aqueous) removed $97.3 \%$ of the alkali metals and alkaline earth. In addition, up to $98.4 \%$ of the chlorine and $88.8 \%$ of the phosphorus were removed under these conditions. In comparison, under the most mild conditions tested (no catalyst, $25^{\circ} \mathrm{C}$ and $90 \mathrm{wt} \%$ aqueous), $6.8 \%$ of the alkali metals and alkaline earth metals, and $19.0 \%$ of the phosphorus were removed. However, $88.0 \%$ of chloride was still removed. This suggests a simple cold water wash may be an ideal preprocessing step for HTL to remove the corrosive chloride while leaving the majority of the beneficially catalytic alkaline metals and alkaline earth metals in place. However, for catalyzed fast pyrolysis, where the alkaline metals and alkaline earth metals act as inhibitors, a dilute-acid leach may be more beneficial.

Although Table 3 shows that the most effective treatment was the more severe acidic treatment at the highest temperature with the highest aqueous loading, it is worth noting that moderate conditions $\left(0.5 \%\right.$ catalyst and $\left.50^{\circ} \mathrm{C}\right)$ achieved ash removals close to the more severe conditions. These more moderate conditions would likely incur lower costs due to using less acid and heat. As pointed out already, conditions were tested that removed significant amounts of an ash species deleterious for a given thermochemical conversion pathway, while removing relatively small amounts of ash species that may be beneficial to that pathway (i.e., chlorine versus alkali metals and alkaline earth metals for HTL). By understanding how the removal of various ash species is affected by different processing conditions, it is theoretically possible to optimize the leaching conditions with respect to the feedstock ash composition, target conversion pathway, and cost of performing the preprocessing. To accomplish this, it is necessary to understand the functionality between the processing conditions (e.g., temperature, acid catalyst concentration and aqueous loadings) and an independent variable (e.g., ash removal). This functionality could 
then be evaluated against the cost to achieve a given extent of ash removal to determine optimal process conditions. Although the economic analyses of implementing a set of process conditions to achieve a given extent of ash species removal is outside the scope of this work, a recent study did estimate the cost to achieve various extents of ash species removal using acid leaching [39].

To this end, multivariate least-squares analysis was performed on key response variables, including the percentages of organic material $\left(\% \mathrm{Org}_{\mathrm{rem}}\right)$, total ash $\left(\% A s h_{r e m}\right)$, potassium + sodium $\left(\% \mathrm{~K}+\mathrm{Na} a_{r e m}\right)$ and calcium + magnesium $\left(\% \mathrm{Ca}+\mathrm{Mg} \mathrm{g}_{\mathrm{rem}}\right)$ remaining after leaching as functions of the predictor variables aqueous loading (AL), catalyst loading (CL) and temperature (T). Parameters of selected models are shown in Table 4. For simplicity, models are only shown for data gathered from experiments at $95 \mathrm{wt} \%$ aqueous. All models have high coefficients of determination of the fits $\left(R^{2}\right)$, and the root mean square errors of calibration $(R M S E-C)$ are wellmatched to those of cross-validation ( $R M S E-C V)$, indicating good fits to the data. Figure $2 \mathrm{~A}$ uses a surface plot and contour plot to show the results of Model 1 in Table 4 and compare with measured values of organic material for aqueous loadings of $95 \%$. Figure $2 \mathrm{~B}$ compares the measured and predicted values of organic materials for Model 1 and shows that the model provides good fits to the data with similar errors for all three aqueous loadings. It must be remembered; however, that the second-order polynomial fit is an engineering approximation, not a theoretical formula.

Figure 3A shows the measured and modeled (Model 2, Table 4) percent of total ash remaining after leaching $\left(\% A s h_{r e m}\right)$ for aqueous loadings of $95 \%$. The residuals of the model are plotted in supplementary Figure 2A, and predicted values are plotted as a function of measured values in supplementary Figure 2B (similar supplementary figures plot the residuals corresponding to Figures $3-7)$. It is observed that Model 2 fits $\% A s h_{\text {rem }}$ with good accuracy and notably, 
substantially more ash is removed than biomass. Figure 3B plots the percent of total ash remaining after leaching $\left(\% A s h_{r e m}\right)$ as a function of the percent of organics remaining after leaching and includes data from the replicate tests. Notably, leaching at the least severe conditions achieved substantial ash removal with loss of very little organics (less than $1 \%$ ). The replicate tests at more severe leaching conditions removed greater amounts of total ash but also removed nearly stoichiometric amounts of organic material, so that more severe leaching did not reduce the concentration of total ash in the material, in agreement with Figure 1. Figure 3B also shows that experiments with the highest aqueous loading achieved the greatest amount of total ash reduction while minimizing the loss of organic material.

Similar plots for alkali metals (potassium and sodium) and alkaline earth metals (calcium + magnesium) are shown in Figures 4 and 5, respectively. Unusual behaviors are observed in Figures 4A and 5A. In Figure 4A, at a catalyst loading of 1\%, the percent amount of potassium and sodium remaining in the sample $\left(\% \mathrm{~K}+\mathrm{Na} a_{r e m}\right)$ increases with increasing temperature contrary to expectations and contrary to the response with zero catalyst. However, this may be a result of experimental variation propagating through the mathematical model, as in either case, the majority of these species are removed, introducing more significance to any analytical errors. Figures 4B and 5B indicate that nearly all of the alkali metals and alkaline earth metals can be removed using $95 \%$ aqueous loading while retaining between $85 \%$ and $90 \%$ of the organic material.

Ratios of removal for various ash species were calculated and plotted to illustrate how the collected data may be used to inform potential conditions for various applications. As an example, figure 5 shows the ratio of chlorine to alkali metal and alkaline earth metal removal. This illustrates conditions that removed significant amounts of a corrosive ash species (chlorine) 
while removing relatively low amounts of alkali metals and alkaline earth metals, which may be beneficial for some HTL applications that can benefit from the catalytic effects of potassium, sodium and calcium [30].

\section{3 - Combustion Applications}

In addition to considering pyrolysis and HTL, which result in the direct production of bio-oils, possible effects on the suitability of a high-ash feedstock (i.e., multi-pass corn stover) for combustion applications was considered.

Biomass combustion is a method to recoup energy from otherwise unused chemical potential within biomass; typically high-lignin or other fractions otherwise undesirable for conversion to bio-oils. However, biomass combustion releases inorganic compounds that contribute to slagging and fouling deposits and decreased heat-transfer efficiency. Agricultural residues, in particular, are often high in total ash, including silica and potassium and lower in calcium and sodium. Potassium, chlorides and silica may form alkali-chlorides and silicates with low melting temperatures that subsequently deposit as slag and cause fouling. An index developed by Teixeira [40], has been reported to predict the significance of slagging, due to the formation of low-melting eutectics, and is predicated on the ratio of basic to acidic species and is given here:

$$
\frac{\operatorname{Alkaline}(\mathrm{B})}{\operatorname{Acidity}(\mathrm{A})}=\frac{\mathrm{Fe}_{2} \mathrm{O}_{3}+\mathrm{CaO}+\mathrm{MgO}+\mathrm{K}_{2} \mathrm{O}+\mathrm{Na}_{2} \mathrm{O}}{\mathrm{SiO}_{2}+\mathrm{TiO}_{2}+\mathrm{Al}_{2} \mathrm{O}_{3}} \quad \text { Equation } 2
$$

Experimentally, it has been determined that:

$\frac{B}{A}<0.2=$ Low risk of slagging $; 0.2<\frac{B}{A}<0.4=$ Moderate risk of slagging $;$ and that $\frac{B}{A}>0.4=$ High risk of slagging 
Using elemental ash data from Tables 2 and 3, Figure 7 was developed to show the effects of dilute-acid leaching on this index for multi-pass corn stover. As shown in Figure 7, the application of dilute-acid leaching reduced the $\mathrm{B} / \mathrm{A}$ ratio from 0.38 (significant risk of slagging) to nearly 0.05 (low risk of slagging) when $1.0 \mathrm{wt} \%$ catalyst was applied at $90^{\circ} \mathrm{C}$. More mild conditions $\left(0.5 \mathrm{wt} \%\right.$ catalyst at $\left.50^{\circ} \mathrm{C}\right)$ still reduced the ratio to 0.08 (low risk of slagging). This index was applied recently [41] to identify ideal applications for fractions of various feedstocks (both woody and herbaceous) that were generated via air classification [42, 43]. In a similar fashion, combining a dilute-acid leaching preprocessing step with the mechanical fractionation of high-ash fractions may be a viable approach to generating fractions of herbaceous biomass suitable for thermochemical applications while keeping drying costs relatively low. For example, the application of $1.0 \%$ catalyst at $90^{\circ} \mathrm{C}$ resulted in a $97.3 \%$ removal of roughly 19,000 ppm of alkaline metals and alkaline earth metals, which would yield a final concentration of approximately $500 \mathrm{ppm}$. However, given that whole pine is typically between 500 and 2,000 ppm [28, 29], it may be that the dilute-acid leaching of a portion of the corn stover, or a mechanically generated high-ash fraction of the corn stover could yield a feedstock of suitable quality for thermochemical conversions, such as pyrolysis, even after recombination with the unleached bulk feedstock.

\section{Conclusions}


To develop a more robust and lower-risk bioenergy market, conversion processes may need to draw from a wider range of feedstock types and quality. Low-temperature water washing and dilute-acid leaching is a potential approach to mitigating the inorganic inhibitors that render many herbaceous feedstocks unsuitable for thermochemical applications, especially pyrolysis. The data generated here shows that this approach removes up to $97.3 \%$ of the physiological ash species that negatively affect pyrolysis; over $85.0 \%$ of corrosive species that increase capital costs for pyrolysis, HTL and combustion; and minimizes the amount of convertible material that is solubilized and extracted during the process. In addition, by managing the dilute-acid leaching conditions, it is possible to selectively mitigate specific ash species to allow feedstocks to be optimized for specific conversion pathways. The benefits of this approach may increase significantly if coupled to methods developed previously that use mechanical methods to generate feedstock fractions with various quality attributes that make them more economically attractive to selectively target for quality management.

\section{Acknowledgments}

This work was supported by the US Department of Energy, Office of Energy Efficiency and Renewable Energy under DOE Idaho Operations Office Contract No. DE-AC07-05ID14517. Additional analytic support was provided by Rachel Emerson, Manunya Phanphanich and Karen Delezene-Briggs at the INL. Huffman Laboratories performed the ash compositional analyses of untreated and treated samples.

\section{References}


1. Perlack RD, Wright LL, Turhollow AF, Graham RL, Stokes BJ, Erbach DC (2005) Biomass as feedstock for a bioenergy and bioproducts industry: The technical feasibility of a billion-ton annual supply. Technical Report, Oak Ridge National Laboratoy. Accession Number: ADAA436753.

2. Kenney KL, Smith WA, Gresham GL, Westover TL (2013) Understanding biomass feedstock variability. Biofuels 4:111-27.

3. Thompson DN, Campbell T, Bals B, Runge T, Teymouri F, Ovard LP (2013) Chemical preconversion: application of low-severity pretreatment chemistries for commoditization of lignocellulosic feedstock. Biofuels 4:323-40.

4. Tao L, Templeton DW, Humbird D, Aden A (2013) Effect of corn stover compositional variability on minimum ethanol selling price (MESP). Bioresource Technol 140:426-30.

5. Chen XW, Shekiro J, Pschorn T, Sabourin M, Tao L, Elander R, et al (2014) A highly efficient dilute alkali deacetylation and mechanical (disc) refining process for the conversion of renewable biomass to lower cost sugars. Biotechnol Biofuels 7:98-108.

6. Hsu DD, Inman D, Heath GA, Wolfrum EJ, Mann MK, Aden A (2010) Life Cycle Environmental Impacts of Selected US Ethanol Production and Use Pathways in 2022. Environ Sci Technol 44:5289-97.

7. Kenney KL, Smith WA, Gresham GL, Westover TL (2013) Understanding biomass feedstock variability. Biofuels 4:111-27.

8. Carpenter D, Westover TL, Czernik S, Jablonski W (2014) Biomass feedstocks for renewable fuel production: a review of the impacts of feedstock and pretreatment on the yield and product distribution of fast pyrolysis bio-oils and vapors. Green Chem 16:384406.

9. Bridgwater AV (2012) Review of fast pyrolysis of biomass and product upgrading. Biomass Bioenerg 38:68-94.

10. Carrier M, Joubert JE, Danje S, Hugo T, Gorgens J, Knoetze J (2013) Impact of the lignocellulosic material on fast pyrolysis yields and product quality. Bioresource Technol 150:129-38.

11. Foust T, Aden A, Dutta A, Phillips S (2009) An economic and environmental comparison of a biochemical and a thermochemical lignocellulosic ethanol conversion processes. Cellulose 16:547-65.

12. Li C, Knierim B, Manisseri C, Arora R, Scheller HV, Auer M, Vogel KP, Simmons BA, Singh S (2010) Comparison of dilute acid and ionic liquid pretreatment of switchgrass: Biomass recalcitrance, delignification and enzymatic saccharification. Bioresource Techno 101:4900-4906.

13. Schell DJ, Farmer J, Newman M, McMillan JD (2003) Dilute-sulfuric acid pretreatment of corn stover in pilot scale reactor. Appl Biochem Biotech 105:69-86.

14. Deng L, Zhang T, Che DF (2013) Effect of water washing on fuel properties, pyrolysis and combustion characteristics, and ash fusibility of biomass. Fuel Process Technol 106:712-20.

15. Liu X, Bi XT (2011) Removal of inorganic constituents from pine barks and switchgrass. Fuel Process Technol 92:1273-1279. 
16. Dayton DC, Jenkins BM, Turn SQ, Bakker RR, Williams RB, Belle-Oudry D, Hill LM (1999) Release of inorganic constituents from leached biomass during thermal conversion. Energy Fuels 13:860-870.

17. Morey R, Vance V, Sears DL, Tiffany R (2006) Characterization of feed streams and emissions from biomass gasification/combustion at fuel ethanol plants. ASABE Meeting Paper; Volume 64180.

18. Hoskinson RL, Karlen DL, Birrell SJ, Radtke CW, Wilhelm WW (2007) Engineering, nutrient removal, and feestock conversion evaluations of four corn stover harvest scenarios. Biomass and Bioenergy 31:126-136.

19. Yu F, Deng S, Chen P, Liu Y, Wan Y, Olson A, Kittelson D, Ruan R (2007) Physical and chemical properties of bio-oils from microwave pyrolysis of corn stover. Applied Biochemistry and Biotechnology 136:957-970.

20. Thy P, Yu CW, Jenkins BM, Lesher CE (2013) Inorganic Composition and Environmental Impact of Biomass Feedstock. Energ Fuel. 27:3969-87.

21. Mohan D, Pittman CU, Steele PH (2006) Pyrolysis of wood/biomass for bio-oil: A critical review. Energy Fuel 20:848-89.

22. Guo Y, Yeh T, Song WH, Xu DH, Wang SZ (2015) A review of bio-oil production from hydrothermal liquefaction of algae. Renew Sust Energ Rev 48:776-90.

23. Elliott DC, Biller P, Ross AB, Schmidt AJ, Jones SB (2015) Hydrothermal liquefaction of biomass: Developments from batch to continuous process. Bioresource Technol 178:147-56.

24. Akhtar J, Amin NAS (2011) A review on process conditions for optimum bio-oil yield in hydrothermal liquefaction of biomass. Renew Sust Energ Rev 15:1615-24.

25. Ramirez JA, Brown RJ, Rainey TJ (2015) A review of hydrothermal liquefaction biocrude properties and prospects for upgrading to transportation fuels. Energies 8:6765-94.

26. Carpenter D, Westover TL, Czernik S, Jablonski W (2014) Biomass feedstocks for renewable fuel production: A review of the impacts of feedstock and pretreatment on the yield and product distribution of fast pyrolysis bio-oils and vapors. Green Chemistry 16:384-406.

27. Antal MJ (1983) Effects of reactor severity on the gas-phase pyrolysis of cellulose- and kraft lignin-derived volatile matter. Industrial \& Engineering Chemistry Product Research and Development 22:366-75.

28. Dyer TJ, Ragauskas AJ. Deconvoluting chromophore formation and removal during kraft pulping: influence of metal cations. International Symposium on wood, fiber and pulping chemistry, Auckland, New Zealand, May 2005.

29. Sannigrahi P, Ragauskas AJ, Tuskan GA (2010) Poplar as a feedstock for biofuels: A review of compositional characteristics. Biofuels, Bioproducts and Biorefining 4:209226.

30. Li C, Aston JE, Lacey JA, Thompson VS, Thompson DN (2016) Impact of feedstock quality and variation on biochemical and thermochemical conversion. Renewable and Sustainable Energy Reviews 65:525-536.

31. Jonsson L, Alriksson B, Nilvebrant N-O (2013) Bioconversion of lignocellulose: inhibitors and detoxification. Biotechnol Biofuels 6:16. 
32. Selig MJ, Adney WS, Himmel ME, Decker SR (2009) The impact of cell wall acetylation on corn stover hydrolysis by cellulolytic and xylanolytic enzymes. Cellulose 16:711-22.

33. Argyle MD, Bartholomew CH (2015) Heterogeneous catalyst deactivation and regeneration: A review. Catalysts 5:145-269.

34. Suarez-Garcia F, Villar-Rodil S, Blanco CG, Martinez-Alonso A, Tascon JMD (2004) Effect of phosphoric acid on chemical transformations during nomex pyrolysis. Chemistry of Materials 16:2639-2647.

35. Ruddy DA, Schaidle JA, Ferrell Iii JR, Wang J, Moens L, Hensley JE (2014) Recent advances in heterogeneous catalysts for bio-oil upgrading via "ex situ catalytic fast pyrolysis": catalyst development through the study of model compounds. Green Chemistry 16:454-90.

36. Thompson DN, Shaw PG, Lacey JA (2003) Post-harvest processing methods for reduction of silica and alkali metals in wheat straw. Applied Biochemistry and Biotechnology. 105:205-218.

37. Dutta A, Talmadge M, Hensley J, Worley M, Dudgeon D, Barton D, Groenendijk P, Ferrari D, Stears B, Searcy EM, Wright CT, Hess JR (2011) Process design and economics for conversion of lignocellulosic biomass to ethanol. Technical Report. NREL/TP-5100-21400.

38. Figliola RS and Beasley DE (2006) Theory and design for mechanical measurements. $4^{\text {th }}$ Edition, Wiley. Hoboken, New Jersey.

39. Hu H, Cherry R, Westover TL, Aston JE, Lacey JA (Submitted to Bioresource Technology, 2016) Process simulation and cost analysis for removing inorganics from wood chips using combined mechanical and chemical preprocessing.

40. Teixeira P, Lopes H, Gulyurtlu I, Lapa N, Abelha P (2012) Evaluation of slagging and fouling tendency during biomass co-firing with coal in a fluidized bed. Biomass Bioenergy 39:192-203.

41. Thompson VS, Lacey JA, Hartley DH, Jindra MA, Aston JE, Thompson DN (2016) Application of air classification and formulation to manage feedstock cost, quality and availability for bioenergy. Fuel 180:497-505.

42. Lacey JA, Aston JE, Westover TL, Cherry RS, Thompson DN (2015) Removal of introduced inorganic content from chipped forest residue via air classification. Fuel 160:265-273.

43. Lacey JA, Emerson RM, Thompson DN, Westover TL(2016) Ash reduction in corn stover facilitated by anatomical and size fractionation. Biomass and Bioenergy 90:173180 . 


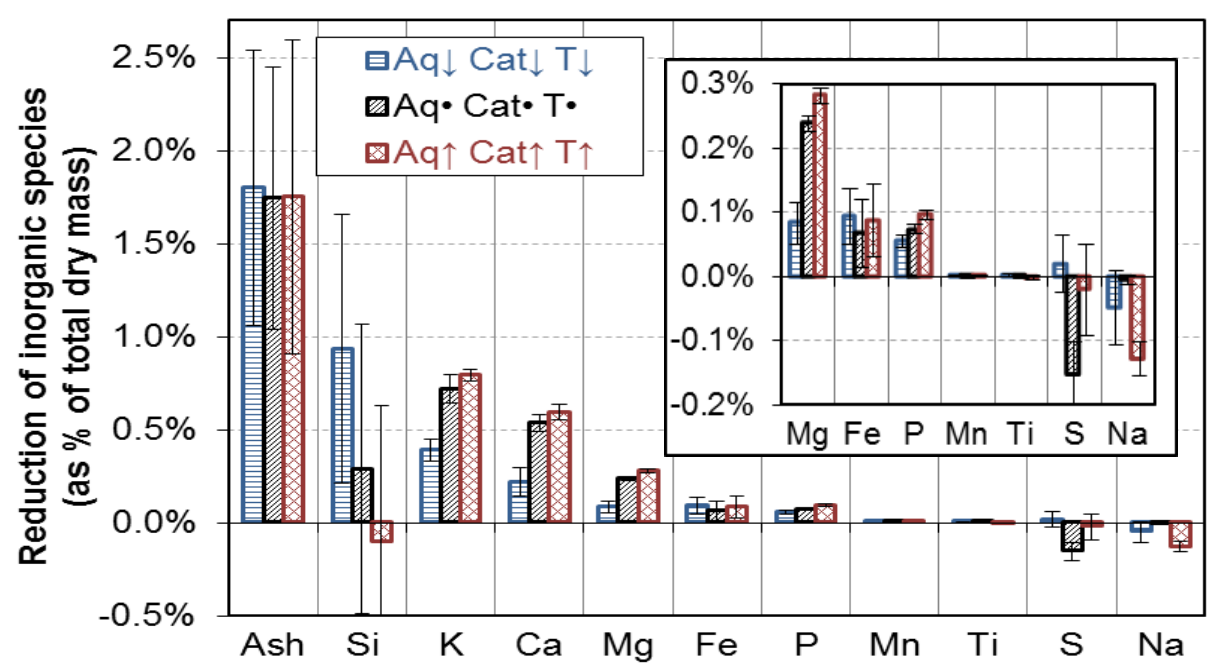

Figure 1. Reduction of inorganic species during replicate leaching tests. Results are shown on a dry basis as a percent of total mass. $\mathrm{T} \downarrow, \mathrm{T} \bullet, \mathrm{T} \uparrow$ refer to the low $\left(25^{\circ} \mathrm{C}\right)$, mid $\left(50^{\circ} \mathrm{C}\right)$, and high $\left(90^{\circ} \mathrm{C}\right)$ temperature conditions, respectively; and $\mathrm{C} \downarrow, \mathrm{C} \bullet, \mathrm{C} \uparrow$ refer to the low $(0.0 \mathrm{wt} \%)$, mid $(0.5$ $\mathrm{wt} \%)$, and high (1.0 wt \%) catalyst loading, respectively. Similarly, Aq $\downarrow$, Aq $\bullet, A q \uparrow$ refer to low, mid and high dilution with aqueous solvent, resulting in $90 \mathrm{wt} \%, 95 \mathrm{wt} \%$, and $98 \mathrm{wt} \%$ aqueous loadings. 

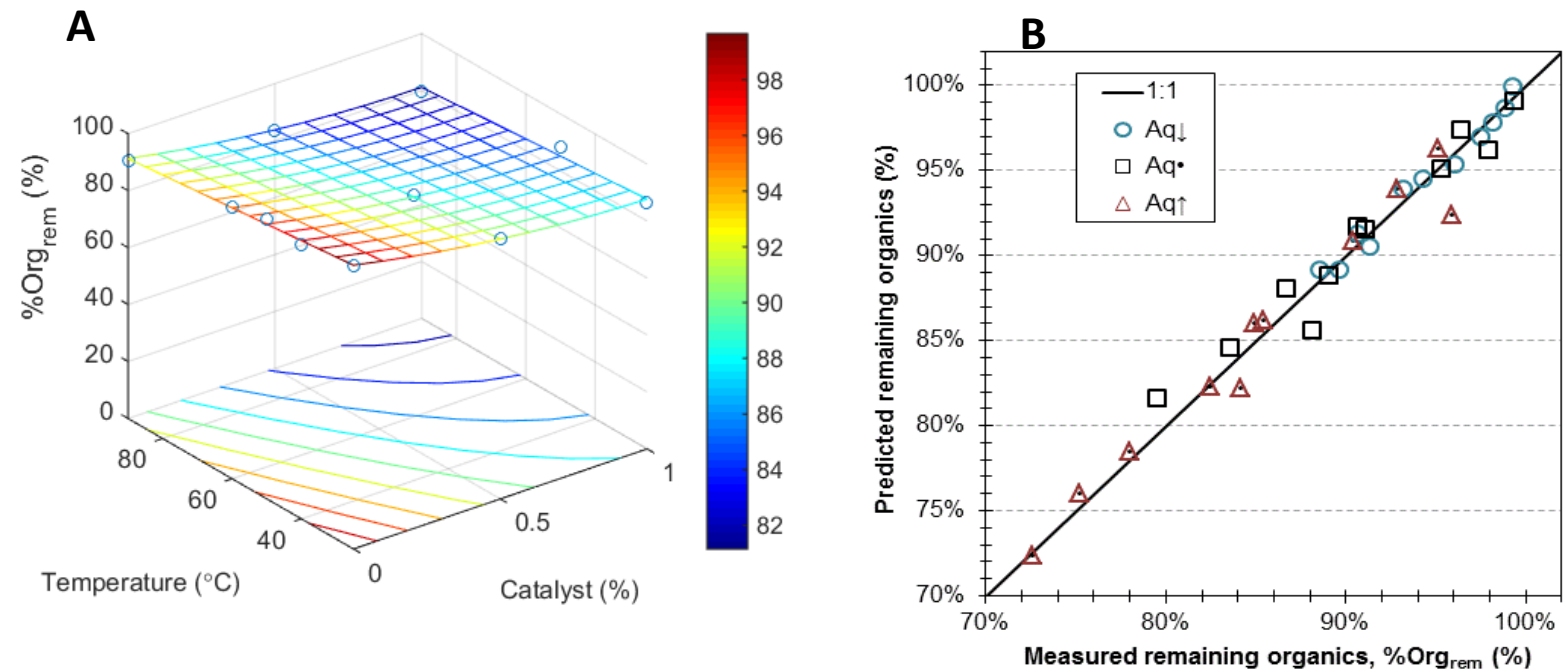

Figure 2. Percent organics remaining after leaching multi-pass corn stover at a $95 \mathrm{wt} \%$ aqueous loading as a function of catalyst concentration and temperature. (A) Shows experimental data points as circles, while the mesh and contours show the fitted model approximation (Model 1 from Table 4). (B) Compares the measured and predicted values of plotted in (A). 

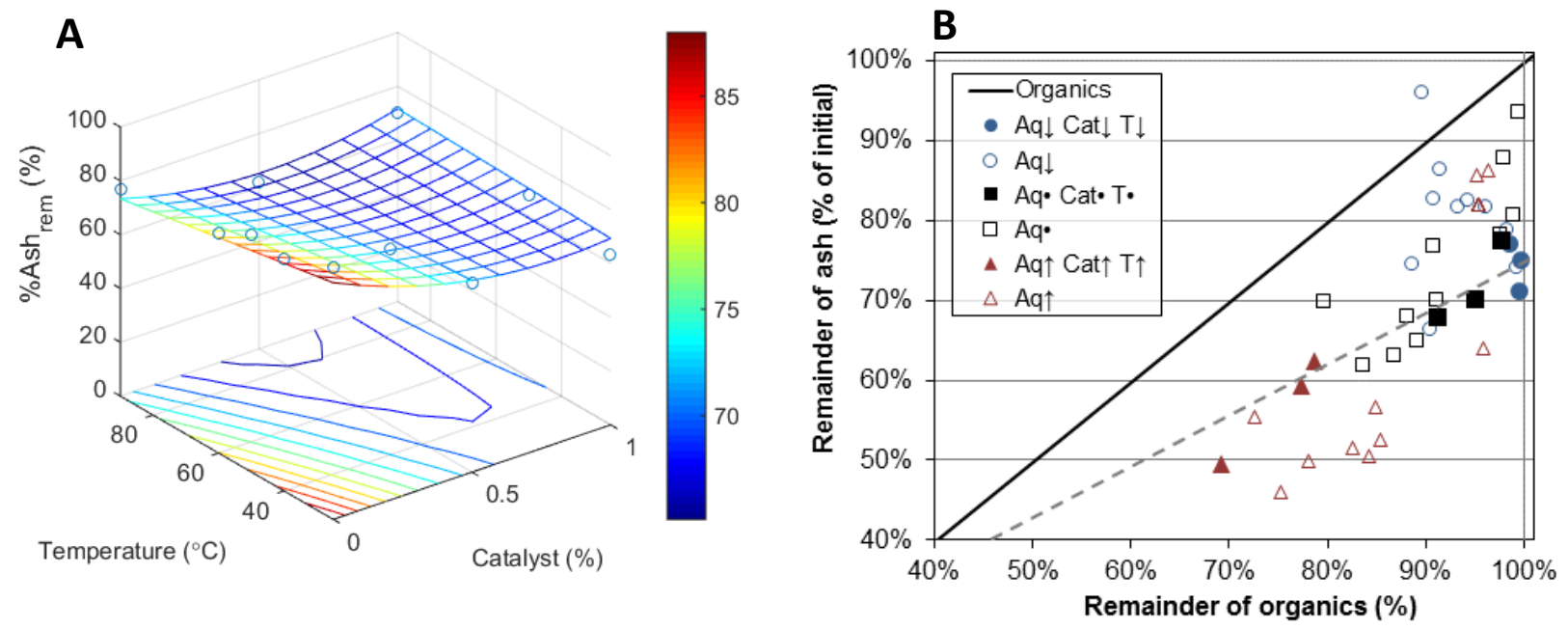

Figure 3. Percent total ash remaining after leaching multi-pass corn stover at a $95 \mathrm{wt} \%$ aqueous loading as a function of catalyst concentration and temperature. (A) Shows experimental data points as circles, while the mesh and contours show the fitted model approximation (Model 2 from Table 4). (B) Shows \%Ashrem as a function of $\% \mathrm{Org}_{\text {rem }}$. 
A

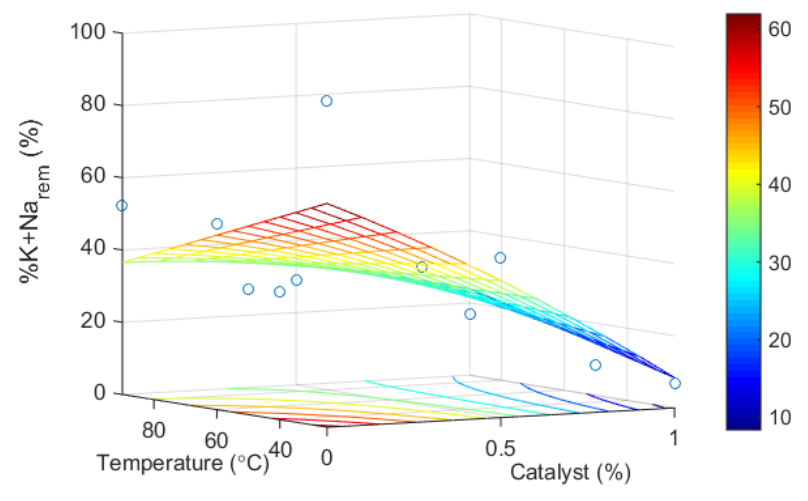

\section{B}

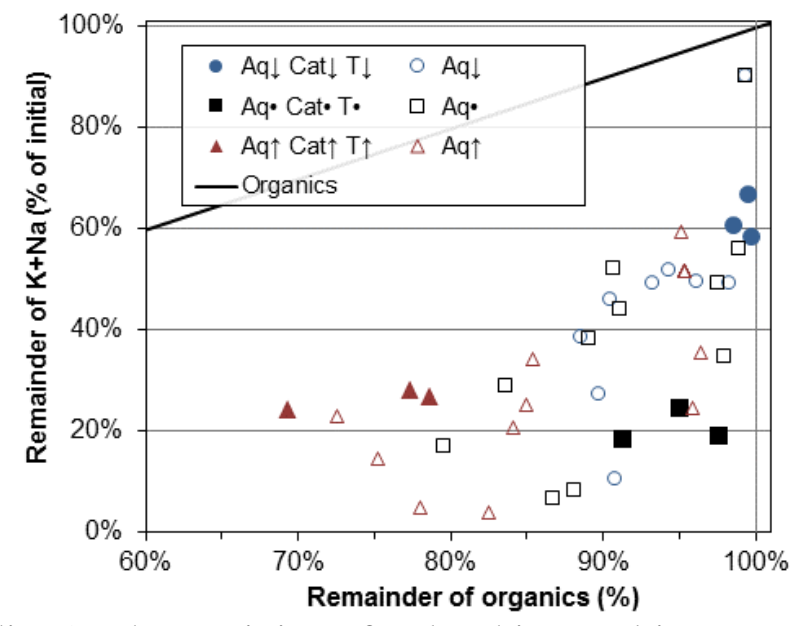

Figure 4. Percent alkali metals (potassium + sodium) ash remaining after leaching multi-pass corn stover at $95 \mathrm{wt} \%$ aqueous loading as a function of catalyst concentration and temperature. (A) Shows experimental data points as circles, while the mesh and contours show the fitted model approximation (Model 3 from Table 4). (B) Shows alkali metal removal as a function of organics removal. 
A

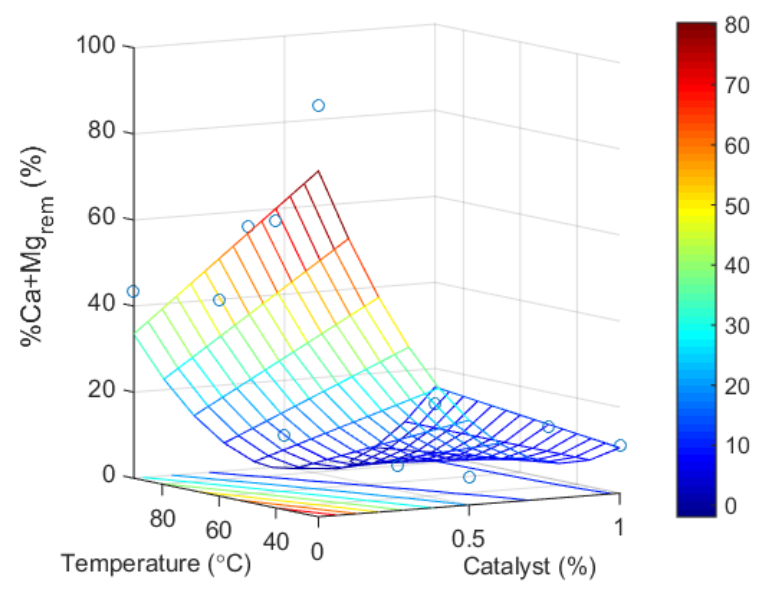

B

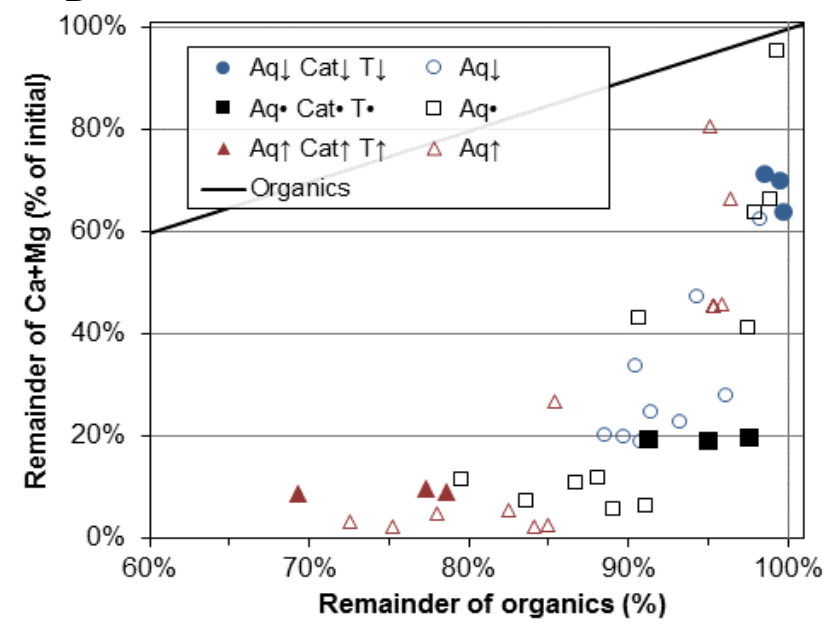

Figure 5. Percent alkaline earth metals (calcium + magnesium) remaining after leaching multipass corn stover at a $95 \mathrm{wt} \%$ aqueous loading as a function of catalyst concentration and temperature. (A) Shows experimental data points as circles, while the mesh and contours show the fitted model approximation (Model 4 from Table 4). (B) Shows alkaline earth metal removal as a function of organics removal. 

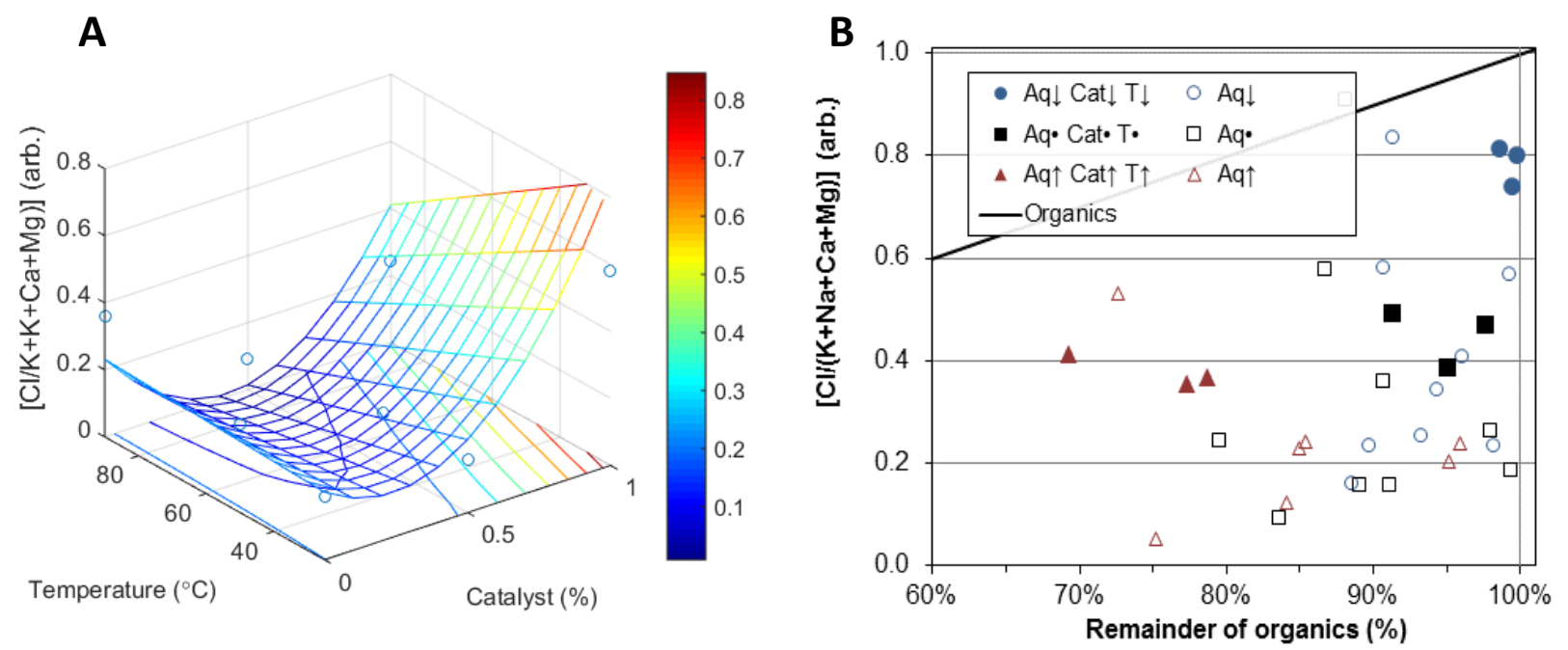

Figure 6. The ratio of chlorine to alkali metals and alkaline earth metals $[\mathrm{Cl} /(\mathrm{K}+\mathrm{Na}+\mathrm{Ca}+\mathrm{Mg})]$ from multi-pass corn stover after dilute-acid leaching at a $95 \mathrm{wt} \%$ aqueous loading as a function of catalyst loading and temperature. (A) Shows experimental data points as circles, while the mesh and contours show the fitted model approximation (Model 4 from Table 4). (B) Shows $[\mathrm{Cl} /(\mathrm{K}+\mathrm{Na}+\mathrm{Ca}+\mathrm{Mg})]$ as a function of organics removal. Arbitrary (arb.) units are shown as the Chlorides do not form oxides during ash analyses. A key result is that the ratio is significantly higher in the absence of catalyst than when catalyst is introduced at $0.5 \mathrm{wt} \%$. This pattern does not hold as catalyst loadings increase to $1.0 \mathrm{wt} \%$. 
A

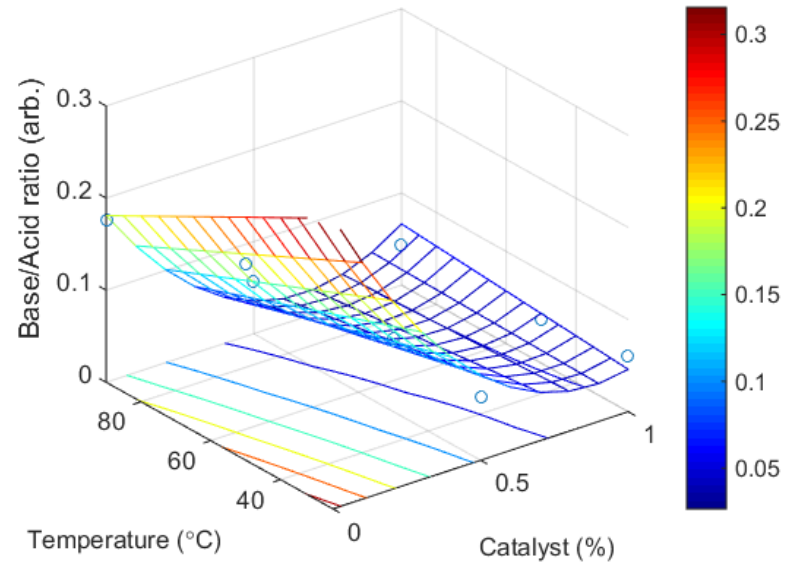

B

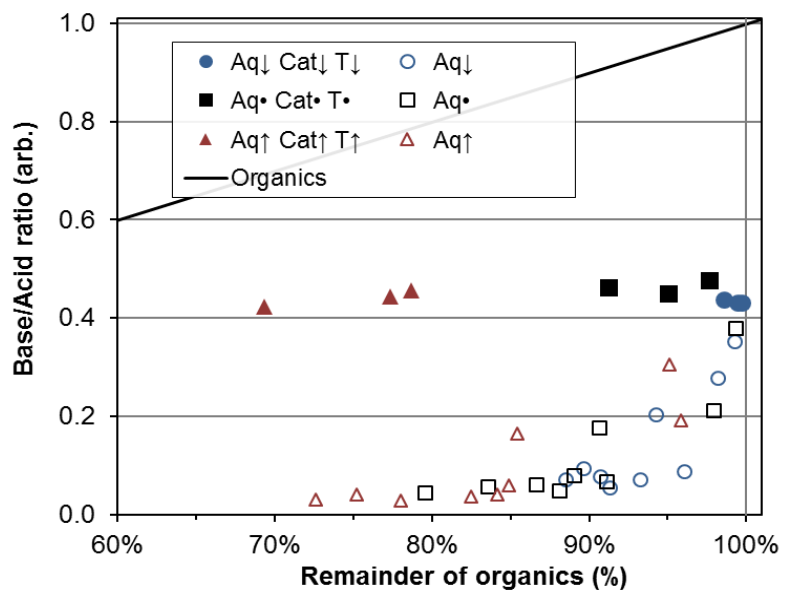

Figure 7. The basic/acidic ratio of ash from multi-pass corn stover after dilute-acid leaching at a $95 \mathrm{wt} \%$ aqueous loading as a function of catalyst loading and temperature. (A) Shows experimental data points as circles, while the mesh and contours show the fitted model approximation (Model 4 from Table 4). (B) Shows basic/acidic ratio of the ash as a function of organic removal. 
Table 1. Experimental matrix showing the conditions tested.

\begin{tabular}{|l|c|c|c|}
\hline \multicolumn{4}{|c|}{ Catalyst $\left[\mathrm{H}_{2} \mathrm{SO}_{4}\right]$} \\
\hline Variables & Minimum & Mid-Point & Maximum \\
\hline Catalyst loading (wt\%) & 0.0 & 0.5 & 1.0 \\
\hline Temperature $\left({ }^{\circ} \mathrm{C}\right)$ & 25 & 50 & 90 \\
\hline Aqueous Loading $(\mathrm{wt} \%)$ & 90 & 95 & 98 \\
\hline
\end{tabular}


Table 2. Total ash (TA), chlorine $(\mathrm{Cl})$, nitrogen $(\mathrm{N})$ and ash composition of untreated multi-pass corn stover. TA and $\mathrm{N}$ are reported in dry wt $\%$ of the corn stover feedstock. Halogens, reported as chlorides $(\mathrm{Cl})$, are given on an ug per dry mass of corn stover basis. Ash composition is reported on a dry wt $\%$, as oxides of the TA. The values shown are average values from six replicates. \pm values indicate $95 \%$ confidence intervals (CI) calculated assuming a t-distribution. $\mathrm{N}$ was measured in duplicate measurements and does not have associated statistics.

\begin{tabular}{|c|c|c|c|c|c|c|c|c|}
\hline Species & Sample 1 & Sample 2 & Sample 3 & Sample 4 & Sample 5 & Sample 6 & Average & 95\% CI \\
\hline $\mathrm{TA}$ & 7.54 & 8.12 & 6.97 & 7.67 & 7.71 & 7.95 & 7.66 & 0.42 \\
\hline $\mathrm{Cl}$ & 387 & 383 & 382 & 383 & 381 & 384 & 383 & 2.2 \\
\hline $\mathrm{N}$ & 0.74 & 0.77 & NA & NA & NA & NA & 0.75 & NA \\
\hline $\mathrm{K}_{2} \mathrm{O}$ & 11.59 & 10.91 & 11.74 & 11.33 & 11.17 & 11.17 & 11.33 & 0.32 \\
\hline $\mathrm{Na} 2 \mathrm{O}$ & 0.45 & 0.52 & 0.44 & 0.48 & 0.49 & 0.49 & 0.48 & 0.03 \\
\hline $\mathrm{CaO}$ & 8.37 & 8.71 & 8.48 & 8.52 & 8.62 & 8.55 & 8.54 & 0.12 \\
\hline $\mathrm{MgO}$ & 4.14 & 3.97 & 4.14 & 4.07 & 4.04 & 3.95 & 4.05 & 0.09 \\
\hline $\mathrm{P}_{2} \mathrm{O}_{5}$ & 1.49 & 1.45 & 1.55 & 1.58 & 1.58 & 1.53 & 1.53 & 0.05 \\
\hline $\mathrm{Fe}_{2} \mathrm{O}_{3}$ & 2.90 & 2.88 & 2.02 & 2.40 & 1.99 & 2.95 & 2.52 & 0.47 \\
\hline $\mathrm{TiO}_{2}$ & 0.14 & 0.15 & 0.13 & 0.13 & 0.14 & 0.15 & 0.14 & 0.01 \\
\hline $\mathrm{SiO}_{2}$ & 65.90 & 66.82 & 65.02 & 67.75 & 68.28 & 65.90 & 66.61 & 1.30 \\
\hline
\end{tabular}


Table 3. Results from experiments varying temperature $\left(\mathrm{T}\right.$, in $\left.{ }^{\circ} \mathrm{C}\right)$, aqueous loading (AL, in wt\%) and catalyst loading (CL, in wt\%) are shown. The final values of total ash (TA) and nitrogen $(\mathrm{N})$ are reported in dry wt\% of the feedstock. The values of halides, reported as $\mathrm{Cl}$ are reported in ug/g dry feedstock, and the values for ash composition are reported as oxides in wt $\%$ of the total ash.

\begin{tabular}{|c|c|c|c|c|c|c|c|c|c|c|c|c|c|}
\hline \multicolumn{3}{|c|}{ Leaching conditions } & \multicolumn{3}{|c|}{$\begin{array}{l}\text { Total ash, nitrogen and } \\
\text { chlorine }\end{array}$} & \multicolumn{8}{|c|}{ Ash composition (wt \% of ash) } \\
\hline $\begin{array}{c}\mathrm{T} \\
{ }^{\circ} \mathrm{C}\end{array}$ & $\begin{array}{c}\mathrm{AL} \\
(\mathrm{wt} \%)\end{array}$ & $\begin{array}{c}\mathrm{CL} \\
(\mathrm{wt} \%)\end{array}$ & $\begin{array}{c}\mathrm{TA} \\
(\mathrm{wt} \%)\end{array}$ & $\begin{array}{c}\mathrm{N} \\
(\mathrm{wt} \%)\end{array}$ & $\begin{array}{c}\mathrm{Cl} \\
(\mathrm{ug} / \mathrm{g})\end{array}$ & $\mathrm{K}_{2} \mathrm{O}$ & $\mathrm{Na}_{2} \mathrm{O}$ & $\mathrm{CaO}$ & $\mathrm{MgO}$ & $\mathrm{P}_{2} \mathrm{O}_{5}$ & $\mathrm{Fe}_{2} \mathrm{O} 3$ & $\mathrm{TiO}_{2}$ & $\mathrm{SiO}_{2}$ \\
\hline 25 & 2 & 0.0 & 6.9 & 0.65 & 46 & 7.9 & 0.5 & 7.5 & 3.9 & 1.2 & 3.1 & 0.2 & 70.5 \\
\hline 25 & 5 & 0.0 & 7.4 & 0.55 & 63 & 10.8 & 0.6 & 8.3 & 3.7 & 1.9 & 3.2 & 0.2 & 66.1 \\
\hline 25 & 10 & 0.0 & 7.8 & 0.69 & 142 & 10.2 & 0.5 & 8.0 & 3.7 & 1.8 & 3.2 & 0.1 & 67.5 \\
\hline 50 & 2 & 0.0 & 5.2 & 0.54 & 22 & 4.2 & 0.4 & 5.5 & 3.1 & 0.5 & 2.7 & 0.1 & 77.6 \\
\hline 50 & 5 & 0.0 & 6.5 & 0.61 & 36 & 4.4 & 0.6 & 6.4 & 2.7 & 0.7 & 3.4 & 0.2 & 77.3 \\
\hline 50 & 10 & 0.0 & 6.1 & 0.65 & 44 & 7.2 & 0.4 & 6.2 & 3.4 & 1.0 & 4.3 & 0.1 & 72.0 \\
\hline 90 & 2 & 0.0 & 4.5 & 0.63 & 18 & 4.1 & 0.4 & 6.1 & 0.4 & 0.8 & 2.9 & 0.2 & 77.0 \\
\hline 90 & 5 & 0.0 & 6.0 & 0.63 & 30 & 2.8 & 0.6 & 6.9 & 0.3 & 0.8 & 4.0 & 0.2 & 78.0 \\
\hline 90 & 10 & 0.0 & 6.2 & 0.63 & 35 & 3.4 & 0.5 & 7.0 & 0.4 & 1.1 & 5.2 & 0.2 & 75.8 \\
\hline 25 & 2 & 0.5 & 4.8 & 0.66 & 6 & 1.0 & 0.5 & 0.6 & 0.0 & 0.5 & 3.5 & 0.2 & 87.7 \\
\hline 25 & 5 & 0.5 & 5.5 & 0.68 & 9 & 2.0 & 0.6 & 1.1 & 0.1 & 0.6 & 2.5 & 0.2 & 87.0 \\
\hline 25 & 10 & 0.5 & 6.1 & 0.68 & 34 & 2.7 & 0.5 & 1.9 & 0.2 & 1.0 & 2.4 & 0.2 & 84.5 \\
\hline 50 & 2 & 0.5 & 4.5 & 0.63 & 3 & 1.2 & 0.4 & 0.5 & 0.0 & 0.5 & 1.8 & 0.2 & 88.7 \\
\hline 50 & 5 & 0.5 & 5.5 & 0.64 & 6 & 1.4 & 0.5 & 1.0 & 0.1 & 0.5 & 4.2 & 0.2 & 85.6 \\
\hline 50 & 10 & 0.5 & 6.1 & 0.69 & 15 & 1.8 & 0.5 & 1.1 & 0.1 & 0.9 & 2.9 & 0.2 & 84.9 \\
\hline 90 & 2 & 0.5 & 3.8 & 0.65 & 1 & 1.1 & 0.3 & 0.6 & 0.1 & 1.1 & 1.9 & 0.2 & 85.9 \\
\hline 90 & 5 & 0.5 & 4.5 & 0.66 & 3 & 1.3 & 0.3 & 0.8 & 0.1 & 1.4 & 2.6 & 0.2 & 84.6 \\
\hline 90 & 10 & 0.5 & 4.9 & 0.66 & 7 & 1.4 & 0.4 & 1.2 & 0.2 & 1.5 & 2.9 & 0.2 & 79.6 \\
\hline 25 & 2 & 1.0 & 4.2 & 0.67 & 18 & 0.7 & 0.4 & 0.5 & 0.0 & 0.5 & 2.0 & 0.2 & 89.1 \\
\hline 25 & 5 & 1.0 & 4.8 & 0.69 & 21 & 1.3 & 0.5 & 0.9 & 0.1 & 0.6 & 2.8 & 0.2 & 87.0 \\
\hline 25 & 10 & 1.0 & 5.8 & 0.69 & 33 & 1.7 & 0.4 & 1.8 & 0.2 & 0.8 & 2.5 & 0.2 & 81.6 \\
\hline 50 & 2 & 1.0 & 4.3 & 0.63 & 16 & 0.5 & 0.3 & 0.3 & 0.0 & 0.4 & 1.6 & 0.2 & 90.1 \\
\hline 50 & 5 & 1.0 & 5.1 & 0.65 & 24 & 0.8 & 0.4 & 1.0 & 0.1 & 0.5 & 2.3 & 0.2 & 88.3 \\
\hline 50 & 10 & 1.0 & 6.0 & 0.69 & 35 & 1.0 & 0.5 & 1.1 & 0.1 & 0.8 & 2.4 & 0.2 & 88.2 \\
\hline 90 & 2 & 1.0 & 4.3 & 0.63 & 6 & 0.4 & 0.2 & 0.5 & 0.1 & 0.3 & 1.5 & 0.2 & 87.7 \\
\hline 90 & 5 & 1.0 & 5.0 & 0.62 & 8 & 1.1 & 0.3 & 1.0 & 0.1 & 0.9 & 1.6 & 0.2 & 87.7 \\
\hline 90 & 10 & 1.0 & $\begin{array}{l}5.9 \\
\end{array}$ & 0.66 & 10 & 1.1 & 0.3 & 1.3 & 0.2 & 1.2 & 5.3 & 0.2 & 83.6 \\
\hline
\end{tabular}


Table 4. Model parameters to fit percentages of organic material (\%Org rem $)$, total ash $\left(\% \mathrm{Ash}_{\mathrm{rem}}\right)$, potassium + sodium $\left(\% \mathrm{~K}+\mathrm{Na}_{\mathrm{rem}}\right)$, and calcium + magnesium $\left(\% \mathrm{Ca}+\mathrm{Mg}_{\text {rem }}\right)$ remaining after leaching as functions of the predictor variables aqueous loading (AL), catalyst loading (CL) and temperature (T). Terms that represented the various interactions were removed from the model if they did not improve the root mean square error - cross validation (RMSE - CV).

\begin{tabular}{|c|c|c|c|c|c|c|}
\hline & $\%$ Org $_{\text {rem }}$ & $\% \mathrm{Ash}_{\text {rem }}$ & $\% \mathrm{~K}+\mathrm{Na} a_{\text {rem }}$ & $\% \mathrm{Ca}+\mathrm{Mg}$ rem & $\mathrm{Cl} /(\mathrm{K}+\mathrm{Na}+\mathrm{Ca}+\mathrm{Mg})$ & $\mathrm{B} / \mathrm{A}$ ratio \\
\hline & Model 1 & Model 2 & Model 3 & Model 4 & Model 5 & Model 6 \\
\hline Intercept & $94.3 \%$ & $67.5 \% *$ & $48.9 \%^{*}$ & $81.2 \% *$ & 0.260 & 0.316 \\
\hline $\mathrm{AL}$ & 2.417 & 7.892 & 5.817 & 4.503 & -0.044 & 0.013 \\
\hline $\mathrm{CL}$ & -27.16 & -69.61 & -54.22 & -193.61 & -0.09 & -0.67 \\
\hline $\mathrm{T}$ & -0.129 & -0.225 & -0.390 & -0.720 & 0.000 & -0.002 \\
\hline $\mathrm{CL}^{2}$ & 9.73 & 29.47 & -10.96 & 102.97 & 1.23 & 0.35 \\
\hline $\mathrm{AL}^{2}$ & -0.139 & -0.535 & -0.251 & -0.214 & 0.006 & -0.001 \\
\hline $\mathrm{CL} \times \mathrm{T}$ & 0.028 & 0.262 & 0.629 & 0.800 & -0.007 & 0.002 \\
\hline $\mathrm{AL} \times \mathrm{CL}$ & 0.956 & 2.976 & -0.816 & 0.166 & -0.062 & -0.002 \\
\hline $\mathrm{R}^{2}$ & 0.953 & 0.831 & 0.746 & 0.911 & 0.783 & 0.949 \\
\hline $\mathrm{RMSE}-\mathrm{CV}$ & $1.97 \% *$ & $7.24 \% *$ & $14.6 \% *$ & $10.7 \% *$ & 0.0018 & 0.00031 \\
\hline
\end{tabular}

* Units are percent of initial species in untreated samples. 